\title{
Стручна звања у библиотечко-информационој делатности у Републици Србији
}

\author{
Иван Стојановић \\ Градска библиотека Вршац \\ ivanstojanovic76@gmail.com
}

\begin{abstract}
Сажетак
Закон о библиотечкој делатности из 1994. године примењивао се у Србији више од две деценије и то у сложеним друштвено-политичким условима којима су свој печат дали дубока економска криза и рат. Истовремено, дошло је до великих промена у библиотечко-информационој делатности, првенствено изазваних наглим развојем информационокомуникационих технологија. Нови закон је стога био нужан, али је донесен тек 2011. године. Заједно са новим одређењем библиотечко-информационе делатности, врста грађе и извора којима се она бави, промењена је и улога библиотекара. Тиме су и стручна звања поново постала предмет интересовања библиотечке јавности. У раду је приказан преглед прописа који се односе на њих, али и низ проблема и питања који су настали изменом правних аката. Посебна пажња посвећена је важећем Закону о библиотечко-информационој делатности и Правилнику о ближим условима за стицање виших стручних звања у библиотечко-информационој делатности који је из њега проистекао.
\end{abstract}

Кључне речи: стручна звања, библиотечко-информациона делатност, Србија, закони, подзаконска акта

\section{Увод}

У Србији је звање библиотекара први пут установљено актом кнеза Александра Карађорђевића 1853. године, којим библиотекар званично постаје и државни службеник. Каснијим законским актима ово звање је прецизније одређено, а библиотекари се стављају у исти ранг са државним чиновницима. Законом о Народној библиотеци из 1901. године, који доноси Александар I Обреновић, краљ Србије, дефинисани су услови за обављање послова у Народној библиотеци Србије: „Народном библиотеком рукује и управља непосредно библиотекар, који се поставља Краљевим указом на предлог Министра просвете... За библиотекара може бити постављен онај који има факултетску спрему и бавио се књижевним радом. Звање библиотекара дели се у три класе с платом...". ${ }^{1}$ Законом се, даље, установљавају радна места помоћника, шефова главних одељака, писара, практиканата и служитеља, као и потребни услови за обављање ових послова.

Наредна законска решења ближе решавају ово питање. У новооснованој Краљевини Срба, Хрвата и Словенаца, касније Краљевини Југославији, такође се формирају друштва, односно удружења библиотекара, која се, између осталог, баве и професијом библиотекара. ${ }^{2}$ Друштво библиотекара НР Србије, након Другог светског рата, као један од својих основних циљева наводи стварање и неговање стручних кадрова. Одмах по почетку рада Друштва библиотекара

\footnotetext{
„Закон о Народној библиотеци“, 1901. преузето 23. 1. 2019, http://www.uzzpro.gov.rs/doc/biblioteka/bib-propisi/kultura-i-prosveta/8-Zakon-o-narodnoj-biblioteci-srbije.pdf.

2 Детаљније о томе у: Гордана Стокић Симончић, „Друштво југословенских библиотекара и Библиотекарско друштво Србије:

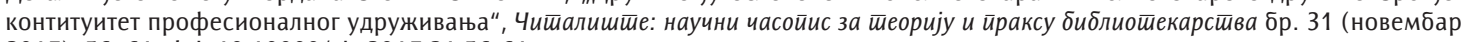
2017): 56-61. doi: 10.19090/cit.2017.31.56-61
} 
НР Србије долази до покретања стручног гласила и отварања средње библиотекарске школе. На основу тадашњег рада и активности, видљиво је да се водило рачуна о питањима струке, образовању кадрова, али и важности признавања библиотекарства као стручног занимања, као и поштовања радника у струци. ${ }^{3}$

Оснивањем нове државе - Федеративне Народне Републике Југославије (ФНР), касније Социјалистичке Федеративне Републике Југославије - СФРЈ), доносе се нови законски прописи. Свака република усвојила је самостално законску регулативу из библиотечко-информационе делатности, па тако и Социјалистичка Република Србија (СР Србија). Аутономне покрајине у њеном саставу (Социјалистичка Аутономна Покрајина (САП) Војводина и Социјалистичка Аутономна покрајина (САП) Косово и Метохија), као и она сама, доносе своја законска решења, у којима постоје неподударности у начинима, условима и процедурама стицања виших стручних звања у библиотечкој делатности. ${ }^{4}$

Закон о библиотечкој делатности СР Србије, ${ }^{5}$ до својих измена 1985. године, не регулише полагање стручног испита у библиотечкој делатности. Он такође не наводи ни стручна звања. Једино прецизира да послове библиотечке делатности могу обављати лица са високом, вишом и средњом стручном спремом (четврти степен) и положеним стручним испитом. Правилником о програму и начину полагања стручног испита библиотечких радника 6 ближе се регулишу ове законске одредбе. Ни Закон, а ни Правилник, уопште не наводе виша стручна звања, нити услове за њихово стицање. Покрајине су имале права да својим законима самостално регулишу ову област.

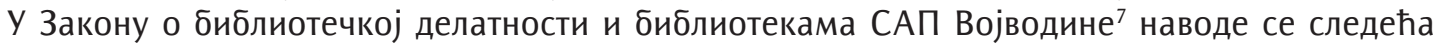
звања у библиотечкој делатности: књижничар, виши књижничар и библиотекар, као и услови за стицање звања. Као виша стручна звања спомињу се виши библиотекар и библиотекар саветник. Закон наводи услове по којима у звање вишег библиотекара може бити изабрано лице које има академски степен магистра или високу стручну спрему и најмање 10 година рада у библиотечкој делатности, као и друге услове. У тексту Закона се такође наводе и даље процедуре око избора у виша звања. Као што се може приметити, овај закон прави разлику између стручног и научног звања.

САП Косово, такође, у Закону о библиотечкој делатности и библиотекама, у одељку 4. Стручна звања, дефинише да стручне послове обављају библиотечки радници који имају једно од стручних звања: књижничар, виши књижничар, библиотекар, виши библиотекар и библиотекар саветник. ${ }^{8}$

\section{Библиотечко законодавство и пратећа акта у Републици Србији 1994-2018}

Усвајањем Закона о библиотечкој делатности из 1994. године ${ }^{9}$ дефинишу се стручна звања, а подзаконским актима и ближи услови за стицање виших стручних звања. Први пут се помињу и нова, са високом стручном спремом (еквивалент стручном називу библиотекар):

\footnotetext{
3 Детаљније о томе у: Десанка Стаматовић, „О библиотекарској професији - историја и перспектива“ у Библиошекарсшво на крају века: зборник раgова (Београд: Библиотекарско друштво Србије, 1996), 3-16; Гордана Стокић Симончић и Жељко Вучковић,

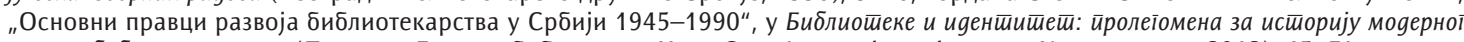
срйскої библиошеккарсӥва (Панчево: Градска библиотека; Нови Сад: Филозофски факултет Универзитета, 2012), 45-71.

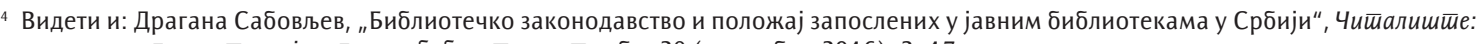
науини иасойис за иееорију и йраксу библиойекарсиива бр. 29 (новембар 2016): 3-17.

5 "Zakon o bibliotečkoj delatnosti“, Službeni glasnik SR Srbije br. 44 (1977), 9 (1984), 24 (1985), u Dragan Barać, prir., Zbirka propisa o bibliotečkoj delatnosti i bibliotekama (Beograd: Minel - Privredno finansijski vodič, 1986), 11-18.

${ }^{6}$ "Pravilnik o programu i načinu polaganja stručnog ispita bibliotečkih radnika“, Službeni glasnik SR Srbije br. 19 (1986), u Dragan "Barać, prir., Zbirka propisa o bibliotečkoj delatnosti i bibliotekama, 89-99.

7 „Закон о библиотечкој делатности и библиотекама“, Службени лисше САП Војвоgине бр. 10 (1974); 26 (1976).

8 „Закон о библиотечкој делатности и библиотекама“, Службени лисй САП Косово бр. 24 (1978)

9 "Закон о библиотечкој делатности“, Службени іласник РС бр. 34 (1994), преузето 26. 2. 2019, https://www.nb.rs/view_file.php?file_id=285.
} 
библиограф, археограф, документалиста, информатор и конзертватор, са одговарајућим вишим звањима (уз придев виши и назив саветник као додатак звању). Поред наведених, сада се наводе и виша стручна звања за књижничаре, односно више књижничаре и то самостални књижничар и самостални виши књижничар.

Као подзаконска акта, Министар културе доноси два правилника. Први је Правилник о врсти стручних послова у библиотеци, врсти и степену стручне спреме потребне за њихово обављање. ${ }^{10}$ Овај документ описно дефинише шта су то стручни послови запослених у библиотекама. Други акт је Правилник о ближим условима за стицање звања лица које обављају стручне послове у библиотеци: „Овим правилником утврђују се ближи услови за стицање звања лица која обављају стручне послове у библиотеци, односно организационој јединици друге организације која обавља библиотечку делатност. ${ }^{\prime 11}$ Утврђују се услови под којима лица са законом одређеним звањима могу да стекну виша, односно: виши библиотекар, виши библиограф, виши археограф, виши документалиста, виши информатор и виши конзерватор, као и звања саветника. Оно што се мора приметити јесте да је овај Правилник веома непрецизан када наводи формално образовање кандидата, а посебно када покушава да дефинише јавности доступне радове потребне за стицање вишег стручног звања. Занимљива је и формулација запажених резултата, ${ }^{12}$ захваљујући којој је било могуће додељивати виша стручна звања без икаквих проверљивих критеријума.

Потребе за изменама законске регулативе на пољу библиотекарства видљиве су почетком 21. века, када се мења и комплетна законска регулатива у Републици Србији. До припреме новог закона долази 2003. године, а нацрти се појављују 2004. и 2005. Иницијативу је покренуло Библиотекарско друштво Србије, па се 2006. године одржавају јавне расправе о нацрту Закона о библиотечкој делатности. Он је имао више од десет верзија, али није ушао у законску процедуру усвајања.

Предлози за измене Правилника о ближим условима за стицање виших стручних звања појављују се 2008. и 2009. године. Њих подносе стручна удружења, а они садрже већи број новина у односу на претходни Правилник. Измене садрже део који дефинише рад Републичке комисије за доделу стручних звања у области библиотекарства и информационих наука, начин њеног формирања, услове и правила рада, начин извештавања, као и формалне услове које кандидат мора да испуни приликом подношења захтева за стицање звања. Додаци овом Правилнику су „Бодовна листа стручних радова и других активности“ и листа "Нивои знања".

До промена, односно до званичног рада на измени Закона о библиотечко-информационој делатности не долази све до 2010. године, када Министар културе доноси Решење 13 о образовању радне групе за израду Нацрта закона о библиотекама. Сачињавали су је представници Народне библиотеке Србије (НБС), Библиотеке Матице српске (БМС), Библиотекарског друштва Србије (БДС), Библиотеке града Београда (БГБ) и Народне библиотеке Крушевац. Задатак радне групе био је израда текста Нацрта закона о библиотекама, којим би се извршило усклађивање постојећих правних аката о библиотекама са текућим друштвеним потребама и савременим светским и домаћим искуствима из те области. Рок за израду Нацрта био

\footnotetext{
10 „Правилник о врсти стручних послова у библиотеци, врсти и степену стручне спреме потребне за њихово обављање“, Службени іласник РС бр. 63 (1994).

11 „Правилник о ближим условима за стицање звања лица које обављају стручне послове у библиотеци“, Службени іласник РС бр. $63(1994)$

12 „Под запаженим резултатима подразумевају се: унапређивање рада библиотеке и изградња информационих система у библиотечкој делатности; унапређивање организације рада увођењем нових оригиналних решења и нових технологија; допринос заштити покретних културних добара; унапређивање структуре и организације фондова библиотеке и читалаштва; стручни допринос археографији, изради прописа који уређују библиотечко-информативну делатност и заштиту покретних културних добара“. - Члан 5. „Правилника о ближим условима за стицање звања лица које обављају стручне послове у библиотеци“.

13 Министарство културе и информисања Републике Србије, „Решење о образовању радне групе за израду нацрта Закона о библиотекама" (28. 10. 2010), интерни документ бр. 119-01-196/2009-07.
} 
је 180 дана. Како је Закон требало усагласити са међународим и европским стандардима и прописима, тако се први пут у домаћем законодавству користи термин библиотечко-информациона, уместо библиотечка делатности.

Нацрт текста закона је, пре усвајања коначне верзије предлога, морао проћи кроз институцију јавне расправе, након које би ушао у процедуру усвајања. Одржано је неколико јавних расправа, а стручна и научна јавност дала је своје примедбе. Важно је приметити да се подаци о јавним расправама, текст Нацрта Закона, примедбе на њега, измене текста Нацрта које су проистекле из расправе, ако их је и било, као ни било који податак који се односи на догађаје и документа који су претходили доношењу Закона, не могу пронаћи на веб-страницама Министарства културе и информисања РС, Народне библиотеке Србије, нити у архиви Библиотекарског друштва Србије.

У тексту „Како да постанем библиотекар ${ }^{\prime 14}$ Гордана Стокић Симончић оптимистично гледа на доношење новог Закона о библиотечко-информационој делатности, у смислу унаређења струке и професионализације, како би се професија библиотекара у Србији ставила у равноправну позицију са другим. Решење види у томе да се овом изменом закона учине суштинске промене и да коначно у библиотекама почну да раде дипломирани библиотекари са завршеним основним студијама библиотекарства и информатике и мастером из ове научне дисциплине, или са основним студијама других профила и мастером из библиотекарства, али дипломирани, тј. они који су од високошколске акредитоване институције добили одговарајуће звање. „Не од библиотеке, јер библиотека и није институција формалног образовања, не на стручном испиту који је реликт једног сасвим другачијег система, и не уверење, него диплому која носи одређен број ЕСТS бодова (European Credit Transfer System - Европски систем преноса бодова) и има међународни значај и важење“. Оптимизам проистекао из познавања одговарајућих иностраних решења се, међутим, показао неоснованим.

Закон о библиотечко-информационој делатности ${ }^{15}$ усвојен је 2011. године, а ступио је на снагу 2012. Својим дефинисањем стручних послова и стручне спреме која је за њих потребна, он је отворио понор из кога српско библиотекарство ни до данас није изашло. Законска решења не само што нису допринела професионализацији струке, него су озбиљно довела у питање и стручност запослених у библиотекама.

Њиме се проширује листа стручних послова, односно уводе нова звања у библиотечкоинформационој делатности. Стручне послове поред књижничара (средња стручна спрема) и виших књижничара (виша стручна спрема) обављају библиотекари и, као нова категорија, дипломирани библиотекари. Поред њих, послове у библиотеци могу да обављају и стручњаци других струка и волонтери. Закон даље наводи:

„(3) Послове библиотекара може да обавља лице са стеченим високим образовањем на студијама првог степена у трогодишњем трајању и положеним стручним испитом.

(4) Послове дипломираног библиотекара могу да обављају:

а) лица са стеченим високим образовањем на студијама првог и другог степена у области библиотекарства и информатике, у трајању од најмање четири године и положеним стручним испитом;

б) лица са стеченим високим образовањем на студијама првог и другог степена у другим областима, у трајању од најмање четири године и положеним стручним испитом“. ${ }^{16}$

\footnotetext{
14 Гордана Стокић, „Како да постанем библиотекар?“, Паниеваико иишалищие Година IX, број 16 (мај 2010): 1, преузето 10. 2. 2019, http://www.citaliste.com/casopis/br16/Citaliste_br16.pdf.

15 „Закон о библиотечко-информационој делатности“, Службени іласник Рейублике Србије бр. 52 (2011), преузето 10. 2. 2019, http://www.kultura.gov.rs/cyr/dokumenti/propisi-iz-oblasti-kulture/-zakon-o-bibliotecko-informacionoj-delatnosti.

16 „Закон о библиотечко-информационој делатности“. Видети и: Драган Бараћ, Право у обласши књиіе (Београд: Народна библиотека Србије, 2014). У овој публикацији дата је веома детаљна анализа Закона.
} 
На основу овог закона донета су подзаконска акта која ближе дефинишу положај, стручна звања и усавршавање библиотечких радника: Правилник о Програму стручних испита у библиотечко-информационој делатности, начину њиховог полагања и висини накнаде за рад чланова Комисије за полагање стручног испита; Правилник о ближим условима за обављање библиотечко-информационе делатности јавних библиотека; Правилник о сталном стручном усавршавању у библиотечко-информационој делатности; Правилник о националним стандардима за обављање библиотечко-информационе делатности и Правилник о ближим условима за стицање виших стручних звања у библиотечко-информационој делатности. ${ }^{17}$

Библиотекарско друштво Србије организовало је јавне расправе поводом предлога текста Правилника о ближим условима за стицање виших стручних звања у библиотечко-информационој делатности. Одржане су дискусије са представницима Радне групе која се бавила израдом текста Правилника, а начелно је усаглашен текст документа који је требало усвојити и са којим се сагласила стручна јавност. Као и у претходном случају, код припреме текста новог Закона, записници са јавних расправа, текстови нацрта подзаконских аката који су припремани, извештаји о раду Радне групе, не могу се пронаћи ни у архивама Министарства културе, БДС, а ни у веб-архиви НБС, под чијим окриљем је Радна група деловала. Једини податак који се може пронаћи је Извештај о раду Библиотекарског друштва Србије за 2012. годину. ${ }^{18}$ У њему се наводи да су представник БДС Весна Црногорац и Јасмина Нинков, као представник Заједнице матичних библиотека Србије (ЗМБС), учествовале у раду Радне групе за израду Закона и подзаконских аката у библиотечко-информационој делатности (међу којима се налазио и Правилник о ближим условима за стицање виших стручних звања у библиотечко-информационој делатности) на састанцима одржаваним у Народној библиотеци Србије и да су донети стандарди за све типове библиотека.

Правилник о ближим условима за стицање виших стручних звања у библиотечко-информационој делатности усваја нова стручна звања, у складу са Законом о библиотечко-информационој делатности из 2011. године. Дефинишу се услови за њихово стицање, али овај документ ни у једном свом делу не садржи одељак који се бави законским прописивањем рада Републичке комисије за доделу виших стручних звања, која су предлагана још 2008, а затим и 2012. године у поступку израде овог Правилника. Рад на изради и утврђивању коначног текста овог правилника пратиле су бројне дискусије, а коначан предлог послат је Министарству културе на усвајање крајем августа 2012. године.

Нова подзаконска акта из библиотечко-информационе делатности усвајају се 2013. године. Текст Правилника о ближим условима за стицање виших стручних звања у библиотечко-информационој делатности био је изненађење за целокупну стручну заједницу, поготово за оне који су учествовали у усаглашавању текста Нацрта овог Правилника. Наводе аутора могу да потврде и колеге са којима је вршена размена података. Након имејл преписке са тадашњим секретаром БДС Весном Црногорац, у којој аутор овог рада наводи да се већи део текста Нацрта Правилника који је био избачен при усаглашавању предлога на јавној расправи сада налази у усвојеном Правилнику, добио је одговор да су, упркос противљењима дела чланова Радне групе које су чинили представници НБС, БМС, БДС и ЗМБС, многа решења остала иста. Записници са јавних расправа, извештаји и записници Радне групе опет остају недоступни јавности.

\footnotetext{
17 „Правилник о Програму стручних испита у библиотечко-информационој делатности, начину њиховог полагања и висини накнаде за рад чланова Комисије за полагање стручног испита“, Службени іласник РС бр. 123 (2012); "Правилник о ближим условима за обављање библиотечко-информационе делатности јавних библиотека“, Службени іласник РС бр. 13 (2013); „Правилник о сталном стручном усавршавању у библиотечко-информационој делатности“, Службени іласник РС бр. 18 (2013); "Правилник о националним стандардима за обављање библиотечко-информационе делатности“, Службени іласник РС бр. 39 (2013); „Правилник о ближим условима за стицање виших стручних звања у библиотечко информационој делатности“, Службени іласник РС бр. 22 (2013).

18 Библиотекарско друштво Србије, „Извештај о раду за 2012. годину“, преузето 12. 2. 2019, https://bds.rs/wp-content/uploads/2013/08/IZVESTAJ-O-RADU-BDS-ZA-2012.pdf
} 
После бурних реакција путем имејл преписки, друштвених мрежа и готово отворених сукоба мишљења у вези са донетим Правилником, јавности се упућује позив да присуствује представљању новог Правилника којега је требало да уприличи Републичка комисија за доделу звања. Већина чланова Републичке комисије у Позиву је потписана својим именом и новим звањима (дипломирани библиотекар, виши дипломирани библиотекар, дипломирани библиотекар саветник). Ко им је у међувремену доделио статус дипломираних библиотекара, остало је нејасно, па је могуће закључити да су га ретроактивно доделили сами себи. На овом састанку су и сами чланови Комисије признали да Правилник није савршен, па је стога дат предлог да се у наредном периоду председнику Републичке комисије доставе предлози за измене, а да ће они у најскоријем периоду бити размотрени. После састанка са председницима матичних комисија, Републичка комисија за доделу виших звања објављује закључке ${ }^{19}$ који су требали да олакшају рад комисија датим објашњењима. О захтевима за измену Правилника није било ни речи, иако су они пристизали претходних месеци.

Министар културе фебруара 2014. године доноси Решење $\mathrm{e}^{20}$ о образовању радне групе за израду текста Нацрта закона о изменама и допунама Закона о библиотечко-информационој делатности, „којим би се извршило побољшање постојећих решења садржаних у Закону о библиотечко-информационој делатности (...) Задатак Радне групе је да изради текст Нацрта закона о изменама и допунама Закона о библиотечко-информационој делатности са образложењем, анализом ефеката закона и потребним материјалом“. ${ }^{21}$ Требало би истаћи да је комисија била састављена од стручних особа, са дугогодишњим искуством у библиотекарству, али оне очигледно нису желеле да се баве питањима професионализације библиотечко-информационе делатности, па је тако и урађен Нацрт Закона. И овога пута, у њему је избегнута промена термина дипломирани библиотекар, што је зачуђујуће, с обзиром на то да се овим термином крше закони, ${ }^{22}$ а Радна група, у којој је било и неколико правника, то није видела као проблем.

После израде Нацрта Закона, спроведена је процедура јавне расправе, током које су изнети предлози за његове измене. Неки од њих односили су се на питања положаја стручних библиотечких радника, као и на стручна звања у библиотечко-информационој делатности. Комплетна документација о раду радне групе, извештаји са јавних расправа, предлози за измене, као и обавештење о прихваћеним, односно одбијеним предлозима, налазе се на веб-страници Министарства културе и информисања РС.23

У Извештају ${ }^{24}$ Савета види се да су предлоге за измену Закона о библиотечко-информационој делатности поднеле, између осталих, др Невена Томић и проф. др Гордана Стокић Симончић, а примедбе су се односиле на термине за стручне послове, односно стручна звања.

19 „Закључци са заједничког састанка Републичке комисије за доделу виших стручних звања у библиотечко-информационој делатности са председницима матичних комисија“, Народна библиотека Србије, 13. септембар 2013. године, преузето 15. 2. 2019, https://www.nb.rs/view_file.php?file_id=3939.

20 Министарство културе и информисања Републике Србије, „Решење о образовању радне групе за израду Нацрта закона о изменама и допунама закона о библиотечко-информационој делатности“, преузето 12. 2. 2019, http://www.kultura.gov.rs/docs/ dokumenti/javna-rasprava-o-nacrtu-zakona-o-izmenama-i-dopunama-zakona-o-bibliotecko-informacionoj-delatnosti/resenjeo-obrazovanju-radne-grupe-za-izradu-nacrta-zakona-o-izmenama-i-dopunama-zakona-o-bibliotecko-informacionoj-delatnosti. pdf.

21 Исто.

22 Овде се мисли на чињеницу да једино на дипломи стеченој на било ком универзитету сме да пише одредница „дипломирани“, никако не на потврди о положеном стручном испиту Народне библиотеке Србије или Библиотеке Матице српске, као ни на уверењу о стеченом вишем стручном звању у библиотечко-информационој делатности.

${ }^{23}$ Министарство културе и информисања Републике Србије, „Јавна расправа о нацрту Закона о изменама и допунама Закона о библиотечко-информационој делатности“, преузето 12. 2. 2019, http://www.kultura.gov.rs/cyr/dokumenti/javne-rasprave/ javna-rasprava-o-nacrtu-zakona-o-izmenama-i-dopunama-zakona-o-bibliotecko-informacionoj-delatnosti.

${ }_{24}$ Министарство културе и информисања Републике Србије, „Извештај о спроведеној јавној расправи о Нацрту закона о изменама и допунама закона о библиотечко-информационој делатности“, преузето 13. 2. 2019, http://www.kultura.gov.rs/cyr/ dokumenti/javne-rasprave/javna-rasprava-o-nacrtu-zakona-o-izmenama-i-dopunama-zakona-o-bibliotecko-informacionoj-delatnosti/izvestaj-o-sprovedenoj-javnoj-raspravi-o-nacrtu-zakona-o-izmenama-i-dopunama-zakona-o-bibliotecko-informacionojdelatnosti. 
Наглашавајући да у Републици Србији постоји формално професионално образовање у библиотечко-информационој делатности, Невена Томић (Секција за промоцију и развој формалног библиотекарског образовања Библиотекарског друштва Србије) још наводи и да се оваквим предлогом Закона доноси једно половично решење за запослене у библиотекама које омогућава произвољне оцене стручности, манипулације у систематизацији радних места и у запошљавању кадрова у библиотекама. Гордана Стокић Симончић (Филолошки факултет Универзитета у Београду, Катедра за библиотекарство и информатику) говори о потреби боље сарадње Министарства културе и Министарства просвете и науке, како би се решио положај школских библиотекара, доношењем решења која промовишу професионализацију библиотечко-информационе струке. Обе траже измену постојећег законског решења и предлажу да се Закон измени на тај начин да члан 46. сада гласи:

„Послове дипломираног библиотекара могу да обављају:

а) лица са стеченим високим образовањем на студијама првог и другог степена у области библиотекарства и информатике, у трајању од најмање четири године и положеним стручним испитом;

б) лица са стеченим високим образовањем на студијама првог и другог степена у другим областима, у трајању од најмање четири године, уз обавезу да, три године од запошљавања у библиотеци, стекну 60 ЕСПБ бодова на акредитованим специјалистичким или мастер студијама библиотечко-информационог профила и да положе стручни испит.

Одредба из става б) тачка 4 члана 46 односи се на лица која се запосле у библиотеци после 1. јануара 2016. године."

Образлажући свој предлог, Томић и Стокић наводе да је садашње законско решење у директној супротности са одредбама Закона о високом образовању. ${ }^{25}$ На основу досадашњег решења, Правилник о ближим условима за стицање виших стручних звања у библиотечко-информационој делатности погрешно користи термин дипломирани библиотекар, будући да одредницу "дипломирани“ може да добије само лице „које заврши основне академске студије у обиму од најмање 240 ЕСПБ бодова, односно у трајању од најмање четири године и лице које оствари најмање 240 ЕСПБ бодова на академским студијама првог и другог степена... из оgїоварајуће обла$c \bar{u} u^{\prime \prime}$, како се то наводи у наведеном Закону. Истичу да је диплома јавна исправа коју потписује декан одговарајућег факултета високошколске установе коју она издаје, а да Републичка комисија није институција формалног образовања која има акредитоване програме обуке чија се звања могу изразити еквивалентом у Европском систему преноса бодова. Предложено решење је слично решењу које је урадила Република Хрватска и у складу је са циљевима и праксом која се промовише у земљама Европске уније. Овде је можда потребно и навести да се, изменама закона о школству у Републици Србији, део кадра са вишим образовањем морао дошколовати, односно завршити дипломске студије како би наставио рад у систему образовања.

Радна група се није сложила са овим предлогом измене, наводећи да не постоје довољни кадровски предуслови за школовање одређеног броја библиотекара на основним академским студијама који би задовољили потребе система јавних библиотека у Србији. Међутим, пракса показује да се, упркос постојању двају катедара за библиотекарство и информатику у Pепублици Србији, у библиотекама најмање запошљавају дипломирани библиотекари. Такође, радна група је превидела да у предлогу измене и даље стоје лица са стеченим високим образовањем у другим струкама (уз услов накнадног образовања на акредитованим студијама по запошљавању), али ипак наводи да су библиотечко-информационој делатности за обављање стручних послова веома потребни и други стручни профили. Не би требало улазити у детаљнију анализу да би се проценила стручност образложења наведене Радне групе.

\footnotetext{
25 "Zakon o visokom obrazovanju“, Službeni glasnik Republike Srbije br. 76 (2005); br. 100 (2007) - autentično tumačenje; br. 44 (2010) i 93 (2012), preuzeto 14. 3. 2019, http://www.ff.uns.ac.rs/Files/zakonOVisokomObrazovanju05.pdf.
} 
До промене и измене Закона о библиотечко-информационој делатности никада није ни дошло, иако је Министарство културе у свом Извештају ${ }^{26}$ навело да је преко потребна измена прописа из ове области.

На Форуму Библиотекарског друштва Србије, одржаном 28. септембра 2016, стручна јавност је расправљала и давала предлоге измене Правилника о додели виших стручних звања, који су упућивани и Републичкој комисији. Између осталог, примедбе су се односиле на Бодовну листу и нејасноће које она садржи, као и у вези са условима за стицање звања, ${ }^{27}$ а поново је покренута расправа везана за новоуведено звање gийломирани библиоиеекар.

Претходно урађене анализе, попут извештаја о раду јавних библиотека Србије у периоду од 2000. до 2015. године, ${ }^{28}$ не износе конкретне податке о стручним библиотечким радницима по звањима, иако се тај податак налази у МБС 29 бази Матичног одељења Народне библиотеке Србије. Никакав податак се не наводи ни о броју запослених који су стекли виша стручна звања по старом Правилнику из 1994, а ни по новом, из 2013. године. С обзиром да је ово одељење Народне библиотеке Србије тада носило назив Одељење за истраживање библиотечко-информационог система, оваква анализа је очигледно урађена са намерним избегавањем изношења овакве врсте података који су били доступни. Разлог томе вероватно можемо тражити, али и наћи, у бројним примедбама које је у том периоду упућивала стручна и научна библиотечка јавност, путем јавних расправа, али и форума, ${ }^{30}$ преко секција БДС и дописа подружница овог удружења стручних радника на тему Правилника и Закона о библиотечко-информационој делатности. Примедбе су биле бројне и на рад Радне групе која је припремала текст Нацрта новог Закона, који је имао за циљ да нагомилане нејасноће, нелогичности, али и велике проблеме, реши путем новог и квалитетног законског решења. С обзиром да је аутор овог извештаја био Владимир Шекуларац, начелник наведеног Одељења, али и члан Радне групе за израду текста Нацрта, јасно је зашто су заобиђени подаци о броју запослених са новим вишим стручним звањима. ${ }^{31}$

Са циљем да се овај проблем коначно реши, под кровом националне библиотеке, током 2017. године, нова Радна група ради на изменама и допунама Правилника о ближим условима за стицање виших стручних звања. Како тече њен рад, ко су чланови, какав је крајњи резултат, остаје тајна, јер се још једанпут јавни подаци о томе не могу пронаћи, нити су јавно објављени.

Израда Каталога радних места у култури и нова систематизација поново су довели у центар интересовања питање стручних звања, али и стручног усавршавања запослених. Као посебан проблем изнето је питање статуса библиотекара у другим областима културе, као и у специјалним библиотекама. Приликом израде платних разреда, питање статуса библиотекара и њиховог положаја у друштву још једном је доведено у питање постављањем школских библиотекара у ниже платне групе у односу на своје колеге, стручне сараднике из просвете. Такође, смањен је укупан број радних сати ангажовања библиотекара као стручног сарадника у настави у основним и средњим школама.

26 Министарство културе и информисања Републике Србије, „Извештај о спроведеној јавној расправи...”.

27 Детаљније у „Стручна звања - предлози за унапређење и измене Правилника о ближим условима за стицање виших стручних

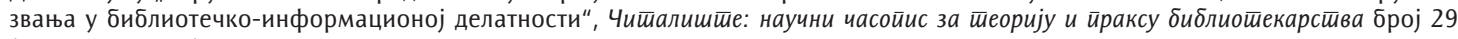
(новембар 2016): 43-51.

28 Владимир Шекуларац, „Мрежа јавних библиотека Србије у периоду од 2000. до 2015. године“, преузето 12. 2. 2019, https:// www.nb.rs/view_file.php?file_id=4853.

29 Мрежа библиотека Србије.

30 Детаљније у „Стручна звања - предлози за унапређење и измене Правилника..."

31 Министарство културе и информисања Републике Србије, „Нацрт закона о изменама и допунама Закона о библиотечко-информационој делатности", преузето 13. 2. 2019, http://www.kultura.gov.rs/cyr/dokumenti/javne-rasprave/javna-raspravao-nacrtu-zakona-o-izmenama-i-dopunama-zakona-o-bibliotecko-informacionoj-delatnosti/nacrt-zakona-o-izmenama-idopunama-zakona-o-bibliotecko-informacionoj-delatnosti. 


\section{Закључак}

Законом о Народној библиотеци Србије из 1901. године јасно се дефинишу услови за обављање послова библиотекара, али и других стручних радника, као и њихова звања и плате. Зашто у свим каснијим законским решењима није било исто тако? Шта је то што професионализацију српског библиотекарства кочи већ више од седамдесет година? Сва каснија законска решења садрже бројне нејасноће и недоречености по питању услова за стицање виших стручних звања у библиотечко-информационој делатности, које ни најновији правни акти нису уредили. Једино што можемо помислити је да је то заправо неком, барем у последњих тридесет година, „ишло на руку“.

Потреба за доношењем новог законског решења на пољу библиотекарства уочава се још почетком новог миленијума. Ипак, српско библиотекарство је на то чекало више од десет година. Међународне смернице, попут IFLA/UNESCO Смернииа за јавне библиоиееке, ${ }^{32}$ очигледно нису довеле до формирања свести о значају професионално едукованих кадрова и њиховом могућем доприносу развоју библиотечко-информационе делатности.

И поред две катедре за библиотекарство и информатику које данас постоје (на Филолошком факултету Универзитета у Београду и на Педагошком факултету у Сомбору, Универзитета у Новом Саду), као и оне основане почетком осамдесетих година, нисмо схватили важност формалног образовања кадрова у библиотечкој професији. Ни најновији Закон о библиотечко-информационој делатности из 2011. године не види академски образоване библиотекаре-информатичаре као стручњаке који би превенствено требало да раде у библиотекама. Њихово формално образовање се по први пут уважава, али се новим стручним звањем дипломирани библиотекар истовремено и брише, с обзиром на то да то звање, ипак, добијају сви запослени у библиотекама са стеченим високим образовањем на студијама првог и другог степена и положеним стручним испитом. Условима за стицање виших стручних звања у области библиотекарства, такође се потцењује формално образовање, јер се изједначавају академска звања, а критеријум за стицање вишег стручног звања су године радног искуства у професији.

Дугогодишњи раздор који постоји између националне библиотеке и Катедре за библиотекарство и информатику Универзитета у Београду заправо се можда и огледа у Закону усвојеном 2011 године. Током готово тридесет година, колико постоји Катедра за библиотекарство и информатику, национална библиотека, која би требало да се брине и о професионализацији струке, никада није озбиљно уважила значај формалног образовања у библиотечко-информационој делатности. Јавне расправе, током којих су изношени предлози за измену Закона о библиотечко-информационој делатности, нису допринеле квалитетнијем законском решењу у делу који се односи на стручност запослених, стављајући стручни испит испред формалног образовања и изједначавајући академски образоване библиотекаре са академски образованим стручњацима из других научних дисциплина. Звање дипломирани библиотекар добијају и они који то заправо нису, а првопотписани новим звањима били су чланови Републичке комисије за доделу виших стручних звања у библиотечко-информационој делатности.

Један део стручних библиотечких радника заузима омаловажавајући став према формално образованим библиотекарима на високошколском нивоу, чиме још више доприноси лошијем општем погледу друштва на библиотечко-информациону професију, не схватајући важност заступања своје професије у целини. Каталог радних места у култури, али и сврставање библиотекара у ниже платне разреде у односу на исту категорију запослених у другим делатностима, јасно је исказао став државе према библиотекарству. Проблем са неуважавањем виших

\footnotetext{
32 IFLA/UNESCO Смернице за развој јавних библиошека (Београд: Народна библиотека Србије; Библиотека града Београда, 2005).
} 
стручних звања у библиотечко-информационој делатности које показују оснивачи који финансирају делатност библиотека и не исплаћују зараду у складу са прописима, додатни је пример лошег односа друштва према библиотечкој професији.

Најновији покушаји измене прописа у библиотечко-информационој делатности не уливају поверење у светлију будућност струке. Нацрт предлога за измену Закона урађен је пре пет година, а измене Правилника о додели виших стручних звања у библиотечко-информационој делатности одвијале су се скривено од очију стручне јавности. Праве разоге за то можемо само наслутити.

Професионализација библиотечко-информационе струке, стручно усавршавање кадрова и системски развој делатности, уз формално образовање, јесу једини пут којим српско библиотекарство може себе довести и одржати на нивоу осталих струка, али и научних дисциплина. Превазилажење личних и професионалних сујета и јединство целокупне стручне јавности у циљу заштите и промоције библиотечке професије може побољшати тренутни положај струке у друштву, које вероватно ни у будућности неће благонаклоно гледати на ову делатност.

\section{Литература и извори:}

1. Barać, Dragan. Pravo u oblasti knjige. Beograd: Narodna biblioteka Srbije, 2014.

2. Barać, Dragan, prir. Zbirka propisa o bibliotečkoj delatnosti i bibliotekama. Beograd: Minel - Privredno finansijski vodič, 1986.

3. Bibliotekarsko društvo Srbije. „Izveštaj o radu za 2012. godinu“. Preuzeto 12. 2. 2019. https://bds.rs/ wp-content/uploads/2013/08/IZVESTAJ-O-RADU-BDS-ZA-2012.pdf

4. IFLA/UNESCO Smernice za razvoj javnih biblioteka. Beograd: Narodna biblioteka Srbije; Biblioteka grada Beograda, 2005.

5. Ministarstvo kulture i informisanja Republike Srbije. „Izveštaj o sprovedenoj javnoj raspravi o Nacrtu zakona o izmenama i dopunama zakona o bibliotečko-informacionoj delatnosti". Preuzeto 13. 2. 2019. http://www.kultura.gov.rs/cyr/dokumenti/javne-rasprave/javna-rasprava-o-nacrtu-zakona-oizmenama-i-dopunama-zakona-o-bibliotecko-informacionoj-delatnosti/izvestaj-o-sprovedenoj-javnojraspravi-o-nacrtu-zakona-o-izmenama-i-dopunama-zakona-o-bibliotecko-informacionoj-delatnosti.

6. Ministarstvo kulture i informisanja Republike Srbije. „/avna rasprava o nacrtu Zakona o izmenama i dopunama Zakona o bibliotečko-informacionoj delatnosti". Preuzeto 12. 2. 2019. http://www.kultura. gov.rs/cyr/dokumenti/javne-rasprave/javna-rasprava-o-nacrtu-zakona-o-izmenama-i-dopunamazakona-o-bibliotecko-informacionoj-delatnosti.

7. Ministarstvo kulture i informisanja Republike Srbije. „Nacrt zakona o izmenama i dopunama Zakona o bibliotečko-informacionoj delatnosti". Preuzeto 13. 2. 2019. http://www.kultura.gov.rs/cyr/dokumenti/javne-rasprave/javna-rasprava-o-nacrtuzakona-o-izmenama-i-dopunama-zakona-o-bibliotecko-informacionoj-delatnosti/ nacrt-zakona-o-izmenama-i-dopunama-zakona-o-bibliotecko-informacionoj-delatnosti.

8. Ministarstvo kulture i informisanja Republike Srbije. „Rešenje o obrazovanju radne grupe za izradu Nacrta zakona o izmenama i dopunama zakona o bibliotečko-informacionoj delatnosti“. Preuzeto 12. 2. 2019. http://www.kultura.gov.rs/docs/dokumenti/javna-rasprava-o-nacrtu-zakona-o-izmenama-idopunama-zakona-o-bibliotecko-informacionoj-delatnosti/resenje-o-obrazovanju-radne-grupe-zaizradu-nacrta-zakona-o-izmenama-i-dopunama-zakona-o-bibliotecko-informacionoj-delatnosti.pdf.

9. Ministarstvo kulture i informisanja Republike Srbije. „Rešenje o obrazovanju radne grupe za izradu nacrta Zakona o bibliotekama" (28. 10. 2010). Interni dokument br. 119-01-196/2009-07.

10. „Pravilnik o bližim uslovima za obavljanje bibliotečko-informacione delatnosti javnih biblioteka“. Službeni glasnik RS br. 13 (2013). 
11. „Pravilnik o bližim uslovima za sticanje zvanja lica koje obavljaju stručne poslove u biblioteci“. Službeni glasnik RS br. 63 (1994).

12. „Pravilnik o bližim uslovima za sticanje viših stručnih zvanja u bibliotečko-informacionoj delatnosti“. Službeni glasnik RS br. 22 (2013).

13. „Pravilnik o nacionalnim standardima za obavljanje bibliotečko-informacione delatnosti“, Službeni glasnik RS br. 39 (2013).

14. „Pravilnik o Programu stručnih ispita u bibliotečko-informacionoj delatnosti, načinu njihovog polaganja i visini naknade za rad članova Komisije za polaganje stručnog ispita“. Službeni glasnik RS br. 123 (2012).

15. „Pravilnik o stalnom stručnom usavršavanju u bibliotečko-informacionoj delatnosti“. Službeni glasnik RS br. 18 (2013).

16. „Pravilnik o vrsti stručnih poslova u biblioteci, vrsti i stepenu stručne spreme potrebne za njihovo obavljanje". Službeni glasnik RS br. 63 (1994).

17. „Sabovljev, Dragana. „Bibliotečko zakonodavstvo i položaj zaposlenih u javnim bibliotekama u Srbiji“. Čitalište: naučni časopis za teoriju i praksu bibliotekarstva br. 29 (novembar 2016): 3-17.

18. Stamatović, Desanka. „O bibliotekarskoj profesiji - istorija i perspektiva“. U Bibliotekarstvo na kraju veka: zbornik radova, 3-16. Beograd: Bibliotekarsko društvo Srbije, 1996.

19. Stokić, Gordana. „Kako da postanem bibliotekar?“. Pančevačko čitalište Godina IX, broj 16 (maj 2010): 1. Preuzeto 10. 2. 2019. http://www.citaliste.com/casopis/br16/Citaliste_br16.pdf.

20. Stokić Simončić, Gordana. „Društvo jugoslovenskih bibliotekara i Bibliotekarsko društvo Srbije: kontituitet profesionalnog udruživanja“. Čitalište: naučni časopis za teoriju i praksu bibliotekarstva br. 31 (novembar 2017): 56-61. doi: 10.19090/cit.2017.31.56-61.

21. Stokić Simončić, Gordana i Željko Vučković. Biblioteke i identitet: prolegomena za istoriju modernog srpskog bibliotekarstva. Pančevo: Gradska biblioteka; Novi Sad: Filozofski fakultet Univerziteta, 2012.

22. "Stručna zvanja - predlozi za unapređenje i izmene Pravilnika o bližim uslovima za sticanje viših stručnih zvanja u bibliotečko-informacionoj delatnosti“. Čitalište: naučni časopis za teoriju i praksu bibliotekarstva broj 29 (novembar 2016):43-51.

23. Šekularac, Vladimir. „Mreža javnih biblioteka Srbije u periodu od 2000. do 2015. godine“. Preuzeto 12. 2. 2019. https://www.nb.rs/view_file.php?file_id=4853.

24. „Zaključci sa zajedničkog sastanka Republičke komisije za dodelu viših stručnih zvanja u bibliotečkoinformacionoj delatnosti sa predsednicima matičnih komisija“. Narodna biblioteka Srbije, 13. septembar 2013. godine. Preuzeto 15. 2. 2019. https://www.nb.rs/view_file.php?file_id=3939.

25. „Zakon o bibliotečko-informacionoj delatnosti“. Službeni glasnik Republike Srbije br. 52 (2011). Preuzeto 10. 2. 2019. http://www.kultura.gov.rs/cyr/dokumenti/ propisi-iz-oblasti-kulture/-zakon-o-bibliotecko-informacionoj-delatnosti.

26. „Zakon o bibliotečkoj delatnosti“. Službeni glasnik RS br. 34 (1994). Preuzeto 26. 2. 2019. https://www. nb.rs/view_file.php?file_id=285.

27. „Zakon o bibliotečkoj delatnosti i bibliotekama“. Službeni list SAP Kosovo br. 24 (1978).

28. „Zakon o bibliotečkoj delatnosti i bibliotekama“. Službeni list SAP Vojvodine br. 10 (1974); 26 (1976).

29. „Zakon o Narodnoj biblioteci“, 1901. Preuzeto 23. 1. 2019. http://www.uzzpro.gov.rs/doc/biblioteka/ bib-propisi/kultura-i-prosveta/8-Zakon-o-narodnoj-biblioteci-srbije.pdf.

30. „Zakon o visokom obrazovanju“. Službeni glasnik Republike Srbije br. 76 (2005); br. 100 (2007) autentično tumačenje; br. 44 (2010) i 93 (2012). Preuzeto 14. 3. 2019, http://www.ff.uns.ac.rs/Files/ zakonOVisokomObrazovanju05.pdf. 


\title{
Professional Titles in Library and Information Activity in the Republic of Serbia
}

\begin{abstract}
Summary
The Law on Library Activity of 1994 was being applied in Serbia for more than two decades, in complex socio-political conditions that were burdened by a deep economic crisis and war. At the same time, there were major changes in library and information activity, caused primarily by the rapid development of information and communication technologies. The new law was therefore necessary, but it was passed only in 2011. Together with the new definition of library and information activity, the types of material and resources it deals with, the role of librarians has changed, too. Thus professional titles became the subject of interest of the library public again. The paper presents an overview of the regulations that apply to them, as well as a series of problems and issues arising from the change of legal acts. Special attention has been paid to the valid Law on Library and Information Activity and the Rule Book on Detailed Requirements for Obtaining Higher Professional Titles in Library and Information Activity.

Based on the presented analysis, the importance of formal education, continuous professional development and systematic development for the professionalization of the library and information profession is emphasized once again, as the only way for Serbian librarianship to reach the level of other professions and scientific disciplines. Overcoming personal and professional vanity and the unity of the entire professional community in order to protect and promote the library profession can improve the current position of the profession in a society that probably will not look on this activity favorably in the future either.
\end{abstract}

Keywords: professional titles, library and information activity, Serbia, laws, bylaws 
